\title{
The Machinery of Ships
}

\section{Some of the Improvements and Tendencies in the Shipbuilding Industry}

\author{
By Lieutenant-Commander H. C. Dinger, U. S. N.
}

THE new large building program for the Navy and 1 the rehabilitation of the shipbuilding industry in this country has brought forth several new and interesting propositions for the machinery installations. This is a particular time for development.

The following new devices are being utilized, each in its most adaptable field.

Turbine reductions gears, etc.

Turbine electric drive installation.

Turbo-electric cruising units in connection with

turbine reduction gears.

Oil burning express boilers, in very large units and embodying improvement in baffling and water circulation.

Superheaters in connection with express boilers.

Oil engines, the semi-Diesel for small powers and the Diesel for moderate powers.

\section{New Problems}

The European war and the great activity of the torpedo has indicated the need for special underwater protection on capital vessels and the need for isolatin different parts of the machinery installation so that damage to one part will not affect others. This has called for machinery layouts much more thoroughly protected than those that have gone before.

The call for speed has also been specially emphasized by the influences of the war. This demand for speed is very insistent and with it appears the rather difficult requirement that it must be produced without sacrifice of the defensive and offensive qualities of the vessel and that the cost must be within reasonable limits.

There are several methods of obtaining the extra speed required. One large the displacen Onplacement and thereby increase the cost. The other is to improve the fuel economy so that the weight of fuel to be carried for a certain radius will be decreased and so that the required boiler capacity can be reduced.

Another is to make changes in design that will enable the machinery to be more compact and lighter. Lightness can to a considerable extent be secured by utilization of better and stronger material.

More power on less total weight can be secured by: (1) Improvement in fue economy, this improvement to be considered and applied in the design and construction of all parts.

(2) A better and more appropriate design of all the component parts so that required to fulfil its function with relation to all the other parts. To secure this ideal balance is the aim of the expert designers, its success is depended upon exact knowledge of performances of engineering devices and the strength and properties of engineering material.

Each unit weight or unit surface, volume or space that is utilized in the machinery installation should give ideal capacity required by the design and do this with the greatest degree of efficiency.

(3) Reducing weight of machinery by use of better material and by constructional devices that tend to lightness without sacrifice of strength and durability.

The effect of progress along the lines of better economy and more expert proportions may be seen in the $35-\mathrm{knot}$ destroyer design. This design for 35 knots, $26,000 \mathrm{~S}$. H. $P$. requires about the same total weight of machinery and fuel that the previous $31-\mathrm{knot}$ design required. The extra power is secured not merely by adding to the machinery but by putting in more economical machinery and a better proportioning of the various parts.

\section{Turbo Reduction Gears}

This type of machinery is being used for all up-to-date destroyers and scout vessels, and for capital ships wher the electric drive is not employed. It is also used for passenger vessels, freighters and tramp steamers. It will undoubtedly be the future machinery for highpowered vessels, and will practically supersede the directly connected turbine and reciprocating steam engine For commercial vessels of small and moderate powers up to $5,000 \mathrm{~S}$. H. P. it will compete with the oil engine, and in this field the oil engine will probably prevail, provided an oil supply at reasonable cost is at hand.

The turbine reduction gear is suitable for low-powered vessels as well as for the highest powers. It will save considerable weight as compared with directly connected turbines or reciprocating engines and is about ten pe cent more economical than the directly connected turbine or steam engine.

\section{Electric Drive}

For large naval vessels the electric drive enables sub-division and isolation of parts of machinery to be made

It is in this particular that the electric drive ha special advantages. The motors, the generators, the boilers, the piping can be isolated from each other an placed in separate compartments that are but slightly interconnected and in this way a much safer machinery installation is secured.

While the actual installations of the electric drive being made in this country do not obtain any bette economy at full power than reduction gear installation would accomplish, it is expected that at cruising speed the electric drive will show better economy.

There are, however, possibilities of securing much better economy in electric drive installations by utilizin the Ljungstrom turbo-generator which has been de-

matter of maintaining proper gas path and more uniform velocity of gases will add materially to the efficiency of boilers.

We now secure about eighty per cent efficiency on oil fuel boilers, but 90 per cent is within the realms of practicability.

Designs of boiler aiming to secure some of this better efficiency are being put forth and are under construction. Some development and experimental work is necessary, but the possibilities of improvement are there.

\section{Superheat}

Superheat has been used in a more or less haphazard fashion in marine installations. There has, however, been continual progress in it. The full practical advantages due to the use of superheat have not been realized. Superheat is especially advantageous on oil fuel boilers. Superheaters have not caused trouble and do not require special knowledge for their operation.

Superheaters are now being installed on shell and express boilers both in the United States and abroad, and wide extension of their use may be looked for

With high-speed turbines such as are used in connection with the turbo-generators for the electric drive and with the turbo-reduction gears a higher steam temperature can be carried safely. Heretofore, the steam temperature for marine work has been limited to about 500 degrees $\mathrm{F}$. It is believed that a temperature up to 600 derrees $F$. are used on shore and may as well be utilized at sea. As yet superheaters have not been extensively employed on destroyer boilers, but a much more extended use can be looked for in the near future. Superheaters are being used in increasing numbers on new vessels fitted with reciprocating engines or with a combination of reciprocating engines with L. P. turbines.

Oil Engines

Oil engines are, of course, the engines to be utilized for submarines, for which service the high-speed, 4cycle Diesel engine is particularly well adapted. There has been a special advance in the art of building Diesel engines in this country.

There is a marked development of Diesel engine installation for moderate powered freighters and also for tugs, fishing vessels and yachts. There are probably more marine Diesel engines under construction in this country than in any European country and as good engines as any abroad can be built here.

In the stokehold of the U. S. S. "Mississippi"

veloped in Sweden and which secures about ten per cent better economy than other turbo-generators so far used. It is not unlikely that the manufacture of the Ljungstrom apparatus will be undertaken in this country in the near future. The electric drive canbe used in connection with Diesel driven generators as well as with steam driven generators. This matter will be discussed unde the heading of oil engines.

Thus far the electric drive has not been applied to large merchant vessels and is not likely to be. For commercial vessel the flexibility of the electric drive is not essential nor is its increased economy at lowe powers of material advantage. It will probably cos more and weigh more than the turbine reduction gear machinery and at full speed secures no better economy. The electric drive has certain military advantages that are of great practical value, and on these, flexibility, isolation of parts, ability to overhaul parts, economy at lower ranges and superior maneuvering qualities the reasons for its installation in capital vessels rest.

\section{Better Boilers}

The application of superheaters to express boilers and the development of oil burning boilers has also drawn attention to further improvements that can be made in boiler efficiency by securing better circulation of the water and a more efflcient baffling and circulation of the gases of combustion. There are indications that an efficient adaptation of the counter flow principle and the
For naval work the Diesel engine will have a fruitful field, as the motive power for auxiliary vessels such as tion is also highly desirable for small cruisers and gunboats.

The advantage of the oilengineis its increased economy. The oil engine will require less than half the oil fuel required by a corresponding steam plant. For moderate powers the space and weight required (considering machinery and fuel together) are about the same as for a steam plant. The oil engine plant also will require less personnel for its operation, but the operating personnel must be mor oil engine installation also will cost somewhat more (about $25 \%$ ) than the steam plant.

Oil engines are beyond the experimental stage and eliable engines are supplied by numerous firms, an during the next few years a large increase in use of oil engines for marine work may be looked for. For large high powered vessels the Diesel engine installation is too heavy and requires too much space as compared with steam turbine reduction gears, or with turbo-generato electric drive. The Diesel engine is, however, well adapted for use in connection with electric drive installation. By having some of the generators driven by Diesel engines their advantage in economy at cruising speeds can be fully realized. Designs contemplating such arrangements are being considered by manu(Concluded on page 245) 
California and Florida. The variety proved to be unsuited to Florida conditions, but in California it is very productive and highly valued. Almost the entire present planting of the variety in that State can be traced directly back to two of the trees sent there by the Department of Agriculture in 1873.

The navel orange in Brazil, unlike its descendent in California, grows under warm, moist conditions. Seedlings of the bitter or sour orange (Citrus aurantium) are employed almost esclusively as stocks, and the navel orange wood is propagated on them by shield budding in essentially the same way that buds are propagated in the United States.

The navel orange as it occurs near Bahia is large, varying from $3 \mathrm{r} / 2$ to 4 inches in diameter, is yellow green in color, and extremely juicy and sweet. Comparative studies made by the Department of Agriculture show that the Brazilian fruits have a considerably lower precentage of peel than the California fruits and somewhat less fibrous matter or "rag." The California orange, however, has a much larger percentage of both citric acid and sugar.

Bud wood from a number of the most promising strains of the Bahia navel orange trees was brought to the United States by the department's plant explorer and is being tested in California and Florida. It is pointed out by the department that because of the important effect of climate on the size and character of the fruit it is impossible to determine in advance whether strains which appear desirable in Bahia will retain their characteristics in the United States. This can be decided only by the tests now under

The German Merchant Fleet (Concluded from page 238)

But perhaps we can exhibit the distribution of these marooned waifs of the sea as well by means of a table as in any other way. The ports which harbor more than 10,000 tons of German steamships are the following:

\begin{tabular}{|c|c|c|}
\hline Port & Vessels & Tons \\
\hline New York. & 24 & 136,597 \\
\hline Rio Janeiro. & 13 & 48,562 \\
\hline Pernambuco.. & 11 & 46,742 \\
\hline Sabang (Sumatra).. & 12 & 44,338 \\
\hline Boston. . . . . . . $\ldots \ldots \ldots$ & 6 & 41,769 \\
\hline Manila........ & 12 & 37,633 \\
\hline Valparaiso. & 11 & 35,623 \\
\hline Las Palmas (Canaries)..... & 12 & 31,066 \\
\hline Montevideo.. & 8 & 27,250 \\
\hline Telok Betong (Sumatra)... & 7 & 23,153 \\
\hline Baltimore $\ldots \ldots \ldots \ldots \ldots$ & 3 & 19,816 \\
\hline Callao....... & 5 & 17,980 \\
\hline Philadelphia. & 4 & 17,892 \\
\hline Teneriffe (Canaries) . . . . . . & 6 & 17,136 \\
\hline Antofagasta (Chile) ....... & 4 & 16,947 \\
\hline Punta Arenas (Chile). & 5 & 16,454 \\
\hline Vigo (Spain) ... & 5 & 15,874 \\
\hline Corral (Chile)... & 4 & 14,869 \\
\hline Trondhjem....... & 2 & 14,641 \\
\hline Honolulu. . . . . . . & 7 & 13,881 \\
\hline Padang (Sumatra) $\ldots . . \ldots$. & 3 & 12,157 \\
\hline Tjilatjap (Java).... & 3 & 11,589 \\
\hline Santos (Brazil).. & 3 & 11,397 \\
\hline Bahia.......... & 4 & 10,638 \\
\hline Pisagua (Chile). & 3 & 10,390 \\
\hline Buenos Ayres.. & 3 & 10,266 \\
\hline Colon. . & 4 & 10,165 \\
\hline Bahia Blanca (Argentine). & 3 & 10,049 \\
\hline
\end{tabular}

In addition to these, we find one or more

In addition to these, we find one or more German merchantmen "in port" in the
harbors of New Orleans, Pensacola, Charleston, Newport News, Jacksonville, Savannah, New London, Clifton, $\bullet$., Southport, N. C., Zamboanga and Cebu, P. I., Hilo, Tutuila (Samoa), San Juan, St. Thomas (in our newly acquired Danish West Indies); Paranagua, Maranhao, West Indies); Paranagua, Maranhao, Cabedello, Santa Catharina, Parahiba, Rio cahuano, Iquique and Coronel, Chile; Rosario and Port Madryn, Argentine; Caleta Buena and Mollendo, Peru; Havana and Cienfuegos; Tampico and Santa Rosalia, Mexico; Cartagena and Sabadilla, Colombian Republic; Curacao, Shanghai, Bangkok; Bilbao, Cadiz, Palma, Almeria, Huelva, Seville, Barcelona, Corunna and Villagarcia, Spain; Surabaya, Amboina and Banjoewangie, Java; and Macassar, Celebes. Truly it seems an insignificant port that does not harbor least one of these German lame ducks.
The Machinery of Ships

(Concluded from page 221)

urers and their actual construction in the near future may be looked for.

The Semi-Diesel engine in which is included the various hot bulb engines are especially adapted for small powers below $500 \mathrm{H}$. P. These engines are simpler than the Diesel, have no air compressors and do not use high compression. They re nearly as economical as the Diesel engine. They are being particularly emloyed in small light powered freighters and in auxiliary sailing vessels. The auxiliary sailing vessel of wood or iron of 1,000 to 3,000 tons displacement is entering the field of the freighter and by its low cost of operation will beat the small tramp steamer as a competitor.

The auxiliary freighter with its oil ngine can make six to nine knots with its machinery alone and with a favorable wind may make 14 knots. The personnel required is no more than that of a sailing vessel of the same size.

The present developments are matters which skill in design and manufacture and the application of high grade materials to specially suitable purposes is needed and wherein highest grade workmanship are fully developed theyns and details ardized and then the manufacture put on an economical basis.

\section{The Unarmored Battleship} (Concluded from page 218)

The warship of highest speed with guns outranging any vessel afloat need carry no side armor for protection against the un. Even the number of guns carried is unimportant except to shorten the time required to destroy an enemy. Once a vessel embodying this idea is built, similar but faster and stronger vessel in a rival's fleet will appear. Thus, we shall see the old course of evolution repeated in a new cycle.

\section{The Battle of the Caribbean} (Concluded from page 227)

whole section of her side armor was driven bodily into the ship. She dropped out of line mortally hurt, and, heeling rapidly, capsized and sank, fifteen minutes after the action opened.

Our leading ships then concentrated on the "Helgoland" and "Ostfriesland," first and second in line; and, in order to cove them, the battle-cruisers, risking the penetration of their belts by our 14's, drew ahead clear of the dreadnought line and closing in to 15,000 yards began to plant their salvos on the Oklahoma and Nevada. Their shells, falling at a steep angle, were dropping on our decks; and it was one of these that pierced the protective deck of the Nevada, smashed a low-pressure turbine, and threw this fine ship out of the line. She stopped and drifted astern. When I last saw her, she was blazing away with her 5-inch batteries at a swarm of German destroyers, which had rushed in, like a crowd of angry terriers, to get he with the torpedo.

The fight had now been on for half an Tour and we were asserting our superiority. The battle-cruiser "Von der Tann" had een badly hit and was settling by the ern. The fire from the German dreadnoughts had perceptibly slackened, and the "Thuringen," at the tail of the column was again in trouble with her steeringear and had fallen behind. Although our ships had been badly knocked about in heir upper works and some of the turret had been disabled, the water-line was
intact on every ship. Victory was in sight, and we on the fire-control platform were jubilantly slapping each other on the back, when, happening to look landards (we were now clearing Cape Maysi, the extreme easterly point of Cuba), ips moving past the point and of warhips moving past the point and bear own diagonally upon our port bow. I touched the spotter on the shoulde "Carlisle, look at that; what is it?"

He swung his glasses upon the fleet (it was clear of the point by now) "That, my
$\$ 1150$ 僁acine Mitchell Junior-a 40 h. p. Six 120-inch Wheelbase

$\$ 1460$ 疍a,ibe 7-Passenger-48 Horsepowe
127-inch Wheelbase

\section{Nitchelle}

\section{The $\$ 1150$ Model}

\section{Another John W. Bate Value}

This year Mitchell Junior -with 120-inch wheelbase - shows another result of factory efficiency. Its size, its power, its beauty and equipment offer amazing value.

Its very purpose is to serve efficiency. It is for men who want a 5 -passenger

car with ample room and power. But who don't want to pay for 7-passenger room and power.

It is for men who want, in a smaller Six, all the Mitchell extra values. But note that it has 40-horsepower. And from hub to hub it measures 120 inches.

\section{Both 100\% Over-Strength}

Both sizes in Mitchells are built to the standard of 100 per cent over-strength. That's twice our former standard. Both are built for lifetime cars-for at least 200,000 miles.

Over 440 parts are built of toughened steel. The

safety parts are all oversize. We use a wealth of Chrome-Vanadium. We test our gears for 50,000 pounds per tooth.

You will find no other car under $\$ 2000$ built anywhere near like the Mitchells.

\section{$\$ 4,000,000$ in Extras}

The Mitchells have extras which, on this year's output, cost about $\$ 4,000,000$.

There are 31 distinct features-like a power tire pump-which nearly all cars omit.

We have this year added 24 per cent to the cost of

finish, upholstery and trimming. This comes from savings in our new body plant, which saves us hundreds of thousands of dollars.

See these extras. You are bound to want them in the car you buy to keep.

\section{Marvels of Efficiency}

The Mitchells show you what factory efficiency can accomplish in motor car building. They are built by John W. Bate, the great efficiency engineer. They are built in a factory which he erected and equipped

-a 45-acre plant. All the extra values are due to his savings. $\mathrm{He}$ has cut our factory cost in two. You will not find like values in any other fine car. Let your Mitchell dealer prove that.

\section{MITCHELL MOTORS COMPANY, Inc. Racine, Wis., U. S. A.}

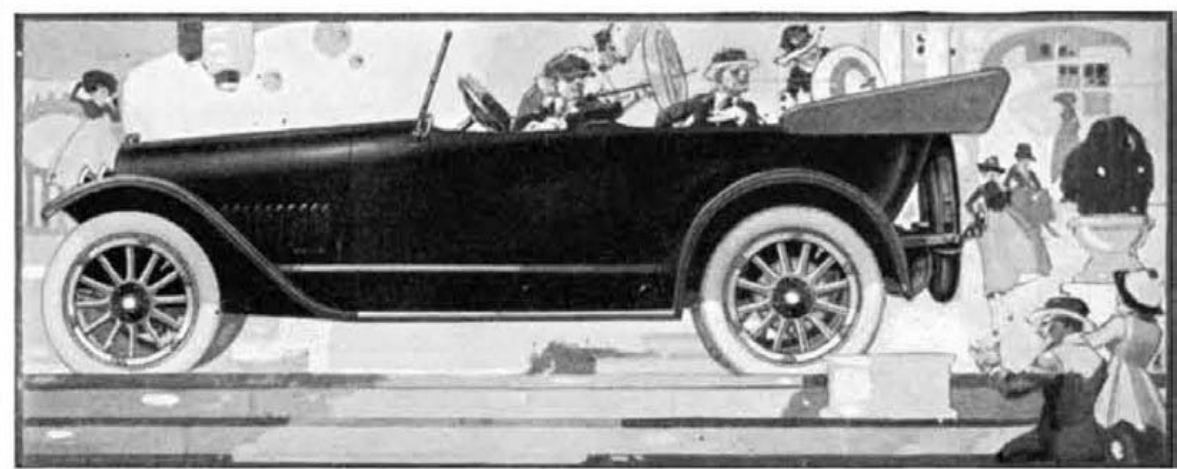

